\title{
INVESTIGATION OF THE CONFORMATION, SOLUBILITY, STRUCTURE AND SELECTIVITY OF ALKALINE PROTEASES IN ANHYDROUS ALCOHOLS.
}

\author{
Shui-Tein Chen ${ }^{1}$, Shiah-Yun Chen ${ }^{1}$, Chen-Chen Tu ${ }^{2}$, and Kung-Tsung Wang ${ }^{1,2,3}$ \\ 1. Laboratory of Biocatalyst, Institute of Biological Chemistry, Academia Sinica., \\ 2. Department of Chemistry, National Taiwan University., \\ 3. Graduate Institute of Biochemical Sciences, National Taiwan University.
}

(Received in USA 30 April 1993)

\begin{abstract}
Summary
The solubility of two alkaline protease, alcalase and subtilisin Carlsberg, in absolute alcohol are determined. The global conformation as well as the local conformation of the active sites (S-1 and S-2 subsites) of both enzymes in alcohol and in aqueous solution are similar. The enantio- and diastereo-selectivity of both enzymes in anhydrous alcohol are also similar to those in aqueous solution.
\end{abstract}

Recently, the search for proteases that are stable in organic solvents for peptide synthesis has been extensive.' Several studies have demonstrated that it is possible to use proteases to catalyse peptide synthesis in organic solvents. ${ }^{2}$ Some enzymes can maintain selectivities in organic solvents, and others cannot. ${ }^{3}$ This report describes a study of solubilities, selectivities, and conformations of two alkaline proteases, alcalase and subtilisin Carlsberg, in anhydrous alcohol. The solubility of both enzymes in anhydrous absolute alcohol was determined by Coomassie Blue method using BSA as a reference. The CD and UV spectra were used to investigate the global conformation of the enzymes in alcohol and the state of enzymes in alcohol. Selective transesterification of substrates, Cbz-DL-amino acid methyl esters and Bz-DL-Ala-L-Phe-OMe, in anhydrous absolute alcohol were used to study the local conformation of the active sites (S-1 and S-2 subsites) of the enzymes in anhydrous alcohol. ${ }^{4} \mathrm{~A}$ procedure for preparing active enzymes in anhydrous alcohols has been reported.

Alcalase is a proteolytic enzyme prepared from the submerged formation of a selective strain of Bacillus licheniformis. The major enzyme component of alcalase is the subtilisin Carlsberg (alkaline protease $\mathrm{A}$ ), which is an extracellular protease and is commercially available as a brown liquid. ${ }^{6}$ Pure alcalase was obtained via dialysis in phosphate buffer to remove the nutrition broth, precipitation by adding isopropanol, and purification by gel filtration on TSK HW-50S gel. Commercial subtilisin Carlsberg (Sigma, Protease VIII, obtained with 11.6 
U.mg-1) was purified to a homogeneous state via TSK HW-50S gel filtration. The alcalase contained a small amount of denatured enzyme, and the subtilisin Carlsberg contained lower MW peptides. The fractions of pure enzyme were collected and used directly (alcalase, 23.7 U.mL ${ }^{-1}$; subtilisin carlsberg 21.4 U.mL ${ }^{-1}$ ) .

Figure 1-a shows the UV spectrum of the alcalase in phosphate buffer and in absolute alcohol, and the denatured alcalase in buffer. The UV spectrum was obtained by measuring the absorbance $(360 \sim 200 \mathrm{~nm})$ of a solution that was prepared by adding $100 \mu \mathrm{L}$ of freshly prepared enzyme solution to $3 \mathrm{~mL}$ of buffer or absolute alcohol, respectively. The patterns of the three spectra are identical. Equal amounts of the enzyme had the same UV absorbance no matter whether in aqueous solution or in absolute alcohol. The denatured alcalase was nearly insoluble in absolute alcohol. In same manner, the UV spectra of pure subtilisin Carlsberg in absolute alcohol was measured and the results are shown in Figure 1-b. The UV spectrum of subtilisin Carlsberg in absolute alcohol and in aqueous solution are idential also.
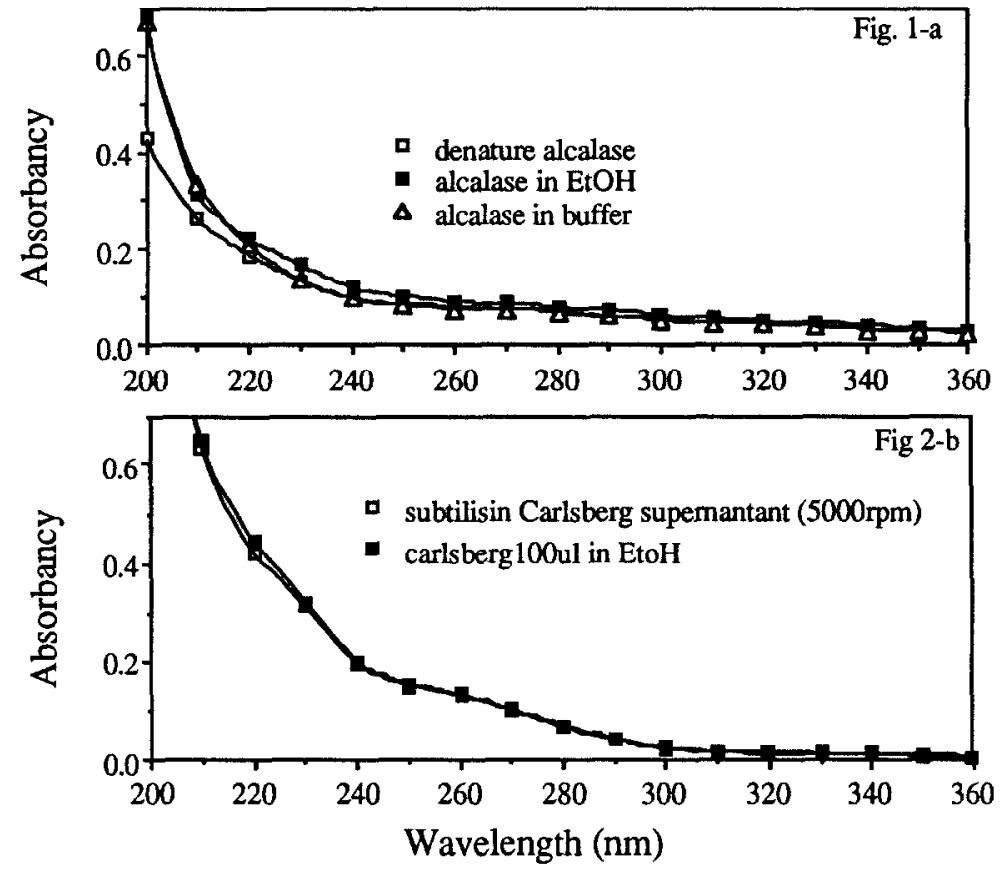

Figure 1. UV spectra of alcalase and subtilisin carlsberg. The UV spectra were measured by adding $100 \mu \mathrm{L}$ of fresh eluted enzyme solution to a cuvette containing phosphate buffer $(10 \mathrm{mM}, \mathrm{pH} 7.0)$ to make the final volume exactly $3.0 \mathrm{~mL}$.

1-a. Alcalase in ethanol, in buffer, and denatured alcalase in buffer. The denatured enzyme was prepared by adding methanol $(5 \mathrm{~mL})$ to the fresh prepared enzyme solution ( $2 \mathrm{~mL}$ ) and incubating for 8 hours. The resulting solution was lyapholized and re-dissolved in water $(2 \mathrm{~mL}) .100 \mu \mathrm{L}$ of the solution was transferred to a cuvette for spectra measurement.

1-b. UV spectra of subtilisin Carlsberg in absolute ethanol. The first spectrum was measured by adding $100 \mu \mathrm{L}$ of fresh eluted enzyme solution to ethanol as described above. The sample solutions of the other two spectra were prepared via precipitation of the freshly eluted enzyme by ethanol for three times, resuspension of the precipitated enzyme in ethanol $(20 \mathrm{~mL})$, anddivision of the resulting mixture into two portions, which were centrifuged for $5000 \mathrm{rpm}$. The superntant was transferred to a cuvette for UV spectra measurement. 
Figure 2 shows the $C D$ spectra of alcalase. The spectra were measured with the same concentration as that in the UV spectra measurement. The CD spectra of both enzymes in alcohol and in phosphate buffer (pH 6.2) are identical and are also identical to a reported spectrum. ${ }^{7}$ The $\mathrm{CD}$ spectra of the denatured enzymes in buffer showed a random structure. The denatured enzyme was insoluble in absolute alcohol, and no CD spectrum was observed. The spectra results showed that the global conformation of the pure alkaline proteases was not changed in alcoholic solvents, and that the conformation of alcalase was similar to that of subtilisin Carisberg. Measurement

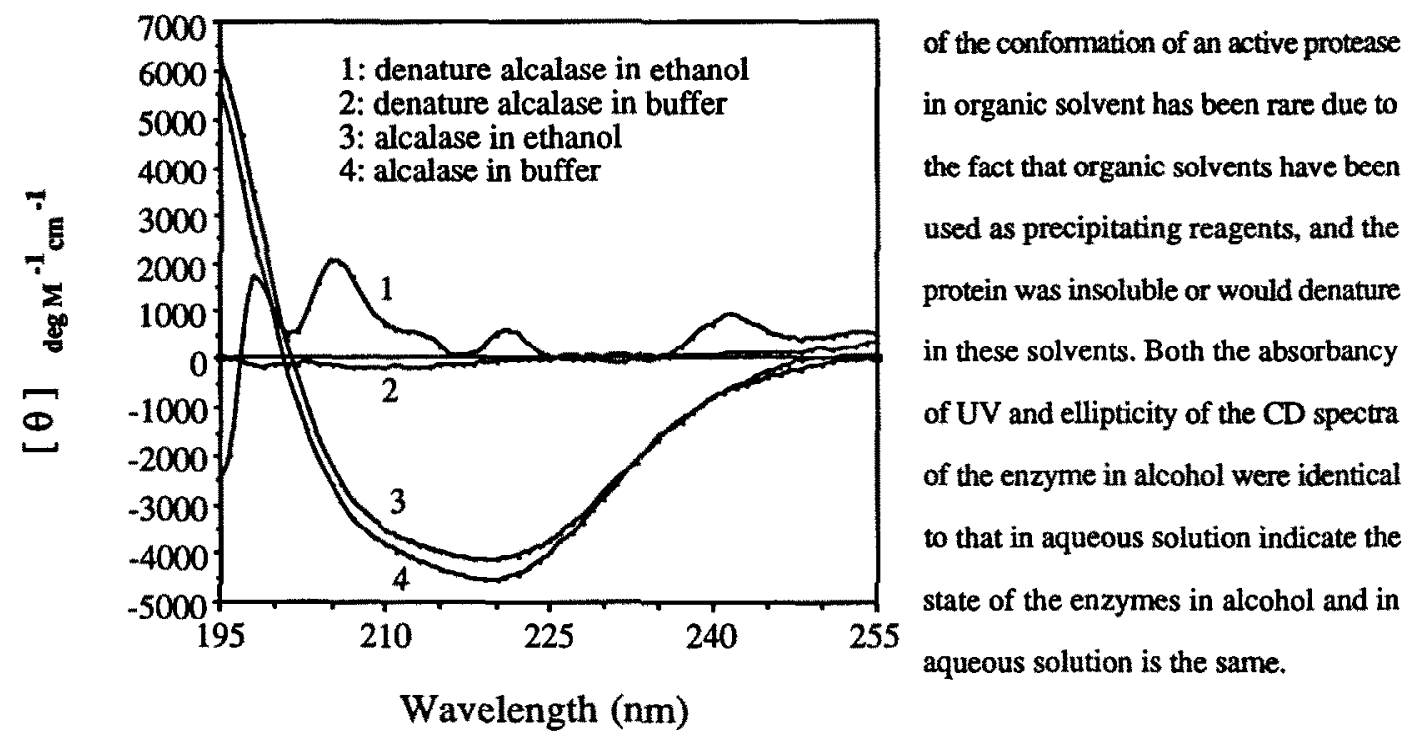

Figure 2. CD measurements were taken on a Jasco-720 spectropolarimeter, using cuvettes of $1 \mathrm{~mm}$ pathlength. Enzyme concentrations were $1.33 \times 10^{-2} \mathrm{mg} / \mathrm{mL}$.

For further investigation solubility of the enzymes in alcohol, a freshly eluted fraction containing active subtilisin Carlsberg was precipitated and centrifuged with absolute alcohol for three times to remove water. ${ }^{5}$ The solubility of the subtilisin Carlsberg and alcalase in alcohol was determined by taking the supernantant and reacted with Coomassie Brilliant Blue G. The solubility of alcalase and subtilisin Carlsberg in absolute alcohol was $0.045 \mathrm{mg} \cdot \mathrm{mL}^{-1}$ and $0.048 \mathrm{mg} \cdot \mathrm{mL}^{-1}$ respectively as measured by the absorbance at $595 \mathrm{~nm}$ using Bovine serum albumin as a reference standard.

Selective trans-esterification using the substrates $\mathrm{Cbz}-\mathrm{D}, \mathrm{L}-\mathrm{AA}-\mathrm{OMe},(\mathrm{AA}=\mathrm{Ala}, \mathrm{Aba}, \mathrm{NorVal}$, NorLeu, Phe) and Bz-DL-Ala-L-Phe-OMe catalyzed by alcalase and subtilisin Carlsberg in absolute alcohol was performed at $35^{\circ} \mathrm{C}$ using HPLC to monitor the reaction. The results are shown on table 1 . The enzymatic activity was determined by measuring the increased concentration of the product in the first $1 \mathrm{~min}$. After about $50 \%$ of the substrate was converted to the ethyl ester, the resulting mixture was evaporated, and the products were isolated 
by preparative HPLC. The enantiomeric excess (e.e.) of the products was determined by a chiral HPLC column, and the e.e. of both products ranged between $100 \% \sim 85 \%$. The optical purity of the diastereoselective products Bz-D-Ala-L-Phe-OMe and Bz-L-Ala-L-Phe-OEt was $98 \%$ and $91 \%$, respectively, as measured by a silica gel HPLC column. Both alcalase and subtilisin Carlsberg had high catalytic reactivity and selectivity in absolute alcohol. The selectivity of alkaline potease catalyzed-transesterification in absolute alcohol was as high as the reported for alcalase catalyzed hydrolysis in aqueous solution ${ }^{8 b, c}$ and in t-butanol containing $5 \%$ buffer. ${ }^{85}$ The results indicated that the conformation of the active site (S-1 and S-2 subsites) of the enzymes in absolute alcohol may be the same as that in aqueous solution.

Table 1. Selective trans-esterification catalyzed by alkaline protease in anhydrous ethanol."

\begin{tabular}{|c|c|c|c|c|c|}
\hline Substrates & enzyme & $\begin{array}{l}\text { initial rate } \times 10^{-3} \\
\mu \mathrm{m} / \mathrm{min} \text {.unit. }\end{array}$ & con & $\begin{array}{l}\text { sion } \\
\text { methyl ester }\end{array}$ & $\begin{array}{l}\text { e.e. (\%) } \\
\text { ethyl ester }\end{array}$ \\
\hline Cbz-Ala-OMe & alcalase & 205.3 & 49 & $97(97)^{b}$ & $100(98)^{b}$ \\
\hline$"$ & subtilisin Carlsberg & 272.8 & 44 & 87 & 100 \\
\hline $\mathrm{Cbz}-\mathrm{Aba}-\mathrm{OEt} \mathrm{t}^{\mathrm{c}}$ & alcalase & 450.7 & 49 & $97^{c}(100)^{b}$ & $96^{c}(97)^{b}$ \\
\hline Cbz-NorVal-OMe & alcalase & 412.6 & 51 & $97(100)^{b}$ & $97(95)^{b}$ \\
\hline Cbz-NorLeu-OMe & alcalase & 221.1 & 49 & $100(96)^{b}$ & $91(98)^{b}$ \\
\hline$"$ & subtilisin Carlsberg & 273.6 & 44 & 89 & 100 \\
\hline Cbz-Phe-OMe & alcalase & 322.9 & 48 & $97(98)^{d}$ & $93(98)^{d}$ \\
\hline Bz-Ala-Phe-OMe & alcalase & - & 46 & 91 & 98 \\
\hline$"$ & subtilisin Carlsberg & - & 44 & 90 & 100 \\
\hline
\end{tabular}

a.Transesterification activity. To Cbz-DL-AA-OMe (for alcalase, $139 \mathrm{mg}$ of $\mathrm{Cbz}-\mathrm{DL}-\mathrm{Ala}-\mathrm{OMe}, 80 \mathrm{mg}$ of Cbz-DL-Aba-OEt, $105 \mathrm{mg}$ of Cbz-DL-NorVal-OMe, $138 \mathrm{mg}$ of Cbz-DL-NorLeu-OMe, $102 \mathrm{mg}$ of Cbz-DLPhe-OMe was used; for subtilisin Carlsberg, $47 \mathrm{mg}$ of Cbz-DL-Ala-OMe, $81 \mathrm{mg}$ of Cbz-DL-NorLeu-OMe were used) dissolved in absolute ethanol $(7 \mathrm{~mL})$ was added a freshly prepared ethanol solution $(3 \mathrm{~mL})$ containing alcalase $(1.0 \mathrm{AU})$ or subtilisin carlsberg $(80 \mathrm{mg}, 11.0 \mathrm{u} / \mathrm{mg})$. The resulting solution was stirred at $35^{\circ} \mathrm{C}$. Periodically, aliquots of samples $(0.2 \mathrm{~mL})$ were taken and quenched by the addition of enough $\mathrm{HCl}$ $(0.10 \mathrm{~N}, 0.8 \mathrm{~mL})$ to make a final volume of $1.0 \mathrm{~mL}$. The solution was centrifuged for 5 minutes at $3000 \mathrm{rpm}$, and aliquots $(20 \mu \mathrm{L})$ of the supernatant were analyzed by HPLC using a RP-18 column, a uv detector at 254 $\mathrm{nm}$, and 1:1:0.01 (v/v/v) acetonitrile/water/trifluoruacetic acid as the eluent. The peak area corresponding to $\mathrm{Cbz}-\mathrm{AA}-\mathrm{OMe}$ was determined, and the reaction rates of transesterification were measured by fitting the area to a calibration curve for Cbz-AA-OMe. The reaction was continued until $50 \%$ of the conversion was reached (20-60 min), and then the mixture was quenched by the addition of $\mathrm{HCl}(1.0 \mathrm{~N})$. The products were isolated by preparative HPLC under the same conditions. The enantiomeric excess of amino acid derivatives was determined by using a chiral column (Diacel Chiral WH, using eluent, ipa:n-hex 95:5). The optical purity of diastereomeric peptide was determined using a silica gel column (si 100, using IPA:n-Hex 90:10 as eluent).

b. The data was obtained by resolution in a solution of $5 \%$ buffer $/ 95 \% \mathrm{t}$-butanol (ref. $8 \mathrm{a}$ ).

c. The substrate was an ethyl ester of Aba, and the reaction was conducted in n-propanol solution; thus, the product was an n-propyl ester.

$\mathrm{d}$. The data was obtained by resolution in aqueous solution with $30 \%$ acetone (ref. $8 \mathrm{c}$ ). 
The subtilisin Carlsberg was obtained as a white crystal, which was hard to dissolve in alcoholic solvents. The active subtilisin Carlsberg was prepared by dissolving the enzyme in buffer containing $1 \% \mathrm{CaCl}_{2}$ and treated using the same procedure as for alcalase. ${ }^{5}$ The enzyme prepared in this way was two hundred times as active as the enzyme used in crystal form.

That the alcalase can maintain its enzymatic activity in alcoholic solvents has been documented. ${ }^{36, c}$ This study demonstrates that the alcalase and subtilisin Carlsberg catalyzed-reaction in anhydrous alcohol have the same selectivities as when catalyzed in aqueous solution or in $95 \% \mathrm{t}$-butanol containing $5 \%$ buffer. These results are opposite to those for the subtilisin Carlsberg catalyzed transesterification in other organic solvents. ${ }^{3 e, b}$ In conclusion, the conformation of subtilisin Carlsberg and alcalase in anhydrous alcohol is identical to that in aqueous solution.

\section{Acknowledgment.}

Support for this research provided by the National Science Council, Taiwan, (NSC 81-0208-N-001-70 \& NSC82-0115-C001-01-078M) is gratefully acknowledged.

\section{References.}

1). a) C. H. Wong, K. T. Wang, Experientia, 1991, 47, 1123.

b) V. Schellenberger, H. D. Jakubke, Angew Chem, Int. Ed. Engl. 1991, 30, 1437.

c) A. M. Klibanov. Chemtech. 1986, 16 . 354.

d) L. E. S. Brink, J. Tramper, K. Ch. A. M. Luyben, K. V. Riet, Enzyme Microb. Technol. 1988, 10, 736.

e) Y. L. Khmelnitsky, A. V. Levashov. N. L. Klyachko, K. Martinek, Enzyme Microb. Technol. 1988, $10,710$.

f) M. N. Gupta, Eur. J. Biochem. 1992, 203, 25.

g) M. Waks, Proteins: Structure, Function, and Genetics, 1986, 1, 4.

h) J.S. Dordick, Biotechnol. Prog. 1992, 8, 259.; i) S. H. M.V. Erp, E.O. Kamenskaya, Y. L. Khmelnitsky, Eur. J. Biochem. 1991, 202, 379.

2). a) P. Kuhl, P. J. Halling, H. D. Jakubke, Tetrahydron Letters 1990, $31,5213$.

b) R. Affleck, Z .F. Xu, V. Suzawa, K. Focht, D. S. Clark, J.S. Dordick, Proc. Natl. Acad. Sci. USA, 1992, 89, 1100.

c) H. Kitaguchi, A. M. Klibanov, J. Amer. Chem. Soc. 1989, 111, 9272.

d) M. Stahl, M. O. Mansson, K. Mosbach, Biotech. Letters, 1990, 12(3), 161.

e) H. Kise, Bioorg. Chem. 1990, 18, 107.

f) H. Kise, Y. Tomiuchi, Biotech. Letters 1991, 13, 317.

g) T. Nagashima, A. Watanabe, H. Kise, Enzyme Microb. Technol., 1992, 14. 842.

h) Z. Zhong, J. J. C. Liu, L. M. Dinterman, M. A. J. Finkelman, T.W. Mueller, M. L. Rollence, M. Whitlow, C.H. Wong, J. Amer. Chem. Soc. 1991, 113, 683.

i) C. H. Wong, S. T. Chen, W. J. Hennen, J. A. Bibbs, Y. F. Wang, J. L. C. Liu, M. W. Pantoliano, M. Whitlow, P. N. Bryan, J. Amer. Chem. Soc. 1990, $112,945$. 
j) R.S., Phillips, M.S. Matthews, E. Olson, R.L.V. Tersch, Enzyme microb. Technol. 1990, 12, 731.

k) K. Chen, F.H. Arnold, Biotechnology, 1991, 9, 1073.

3). a) T. Sakurai, A. L. Margolin, A. J. Russell, A. M. Klibanov, J. Amer. Chem. Soc. 1988, $110,7236$.

b) P.A. Fitzpatrick, A. M. Klibanov, J. Amer. Chem. Soc. 1991, 113, 3166.

c) S. T. Chen, S. C. Hsiao, K. T. Wang, Bioorg. \& Med. Chem. Letters. 1991, 1(9), 445.

d) S. T. Chen, S. Y. Chen, K. T. Wang, J. Org. Chem. 1992, 57, 6960.

e) A.M. Klibanov, TIBS 1989, April, 141.

f) S. Riva, J. Chopineau, A.P.G. Kieboom, A.M. Klibanov, 1988, $110,584$.

g) A.L. Margolin, D.F. Tai, A.M. Klibanov, J. Amer. Chem. Soc. 1987, 109, 7885.

4). S.T. Chen, S.H. Wu, K.T. Wang, Int. J. Peptpide Protein Res. 1991, 37, 347.

5). A typical procedure for removing water from the alcalase solution was as follows: the enzyme solution was suspended in an anhydrous alcohol by agitation, the resulting mixture was centrifuged (3000-4000 $\mathrm{rpm}$ ) to separate the enzyme from the solvent, and the alcohol was removed by decantation. The procedure was repeated several times, and the enzyme was then transferred to a reaction flask for be further used. see reference 3-d.

6). Alcalase was purchased from NOVO industrial (Denmark) as a brown liquid with a specific activity of 2.5 AU.mL ${ }^{-1}$. (According to NOVO, one Anson-unit (AU) is the amount of enzyme which, under standard conditions, digests haemoglobin at an initial rate liberating per min an amount of TCA-soluble product, which gives the same color of phenol reagents as 1 mequiv of tyrosine. Thus $1 A U=1000 \mathrm{U}, 1 \mathrm{U}=1 \mathrm{mmol}$ of L-Tyr-OMe hydrolyzed per $\mathrm{min}$ ).

7). G. Merutka, W. Shalongo, E. Stellwagen, Biochem, 1991, 30, 4245.

8). a) S. T. Chen. S. Y. Chen, S. C. Hsiao, K. T. Wang. Biotech. Letters. 1991, 13(11). 773.

b) S. T. Chen, K. T. Wang, C. H. Wong, Chem. Commu. 1986, 1514.

c) S. T. Chen, S. C. Hsiao, A. J. Chiou, S. H. Wu, K. T. Wang, J. Chin. Chem. Soc. 1992, $39,91$. 